\title{
Notes for the reader
}

\begin{abstract}
A few words on religious terminology may be helpful for those unfamiliar with recent histories of the Reformation. Both 'Protestant' and 'Catholic' are used here as broad terms, each encompassing a considerable variety of beliefs. I have also used the vaguer label 'evangelical', mostly when discussing the early Reformation period (up to the mid-I540s or thereabouts). This refers to those whose beliefs we, with hindsight, can recognise as proto-Protestant, but which the 'evangelicals' themselves did not necessarily recognise as such. Even vaguer are the terms 'reformer' and 'reformist', which are applied to both Protestants and Catholics (the enthusiasm of some Catholics for radical reforms of their Church is a significant theme of this book). A little more precision is intended by the terms 'Lutheran' and 'Reformed', each of which refers to distinct Protestant groupings: 'Reformed' Protestantism is the multi-faceted tradition often, but misleadingly, referred to as 'Calvinism'.

All quotations have been rendered into modern English. My own inclination is to a more austere style, but while the English of the sixteenth century is accessible enough to the modern reader, the Scots language is another matter. Its distinctive spellings, usages and vocabulary can be daunting, even for modern Scots. I hope those who share my fondness for those usages will forgive me.

Throughout, the year is reckoned to begin on I January. All sums of money are, unless otherwise noted, in Scottish pounds (of which there were roughly four to the (English) pound sterling for much of this period, but values fluctuated).

Much of chapter 5 is based on my article, 'Reform without frontiers in the last years of Catholic Scotland', English Historical Review II9 (2004), 27-56. I am grateful for permission to draw on that material here.
\end{abstract}

